\title{
Sociocarbon cycles: Assembling and governing forest carbon in Indonesia
}

\begin{abstract}
As Indonesia's REDD+ (Reducing Emissions from Deforestation and forest Degradation) program unfolds, it is transforming people and places in unexpected ways, and reconfiguring human and nonhuman processes. In this paper we recognize that forest carbon governance is about much more than carbon. Reflecting on observations from research in Indonesia, we develop the concept of sociocarbon cycles in an effort to move beyond the human-nature dualisms that characterize much work on REDD+. We see carbon governance as emergent sets of arrangements that are continually tested and challenged through the agency of diverse human and non-human actors. Drawing on insights from the literature on socionatures, and in particular on work on hydrosocial cycles, we approach carbon as a socionatural achievement, constituted through relations among institutions, carbon technologies, and $C$ atoms. Our approach recasts REDD+ as an inherently political program, rather than a technoscientific response to climate change. This, we contend, opens up new ways of conceptualizing and approaching carbon. A sociocarbon lens highlights the importance of social research in reconceptualising biophysical carbon cycles; brings questions of justice and power to the fore (who wins and who loses from carbon initiatives); and aids in understanding what carbon is, how it is made known, and how competing carbon claims are sustained. We suggest that a sociocarbon lens provides multiple points of entry to pursue more just geometries of power.
\end{abstract}

\section{Keywords:}

REDD+; Socionature; Carbon governance; Geometries of power; Forest carbon; Indonesia 


\section{Sociocarbon cycles: Assembling and governing forest carbon in Indonesia}

\section{Introduction}

In the small village of Pendulangan, on the edge of Indonesia's Sungai Lamandau Wildlife Reserve in Central Kalimantan, a middle-aged woman reflects on recent encounters with orangutans. They often emerge from the forest nearby, sometimes ransacking houses in search of food. Various strategies have been used to deter the orangutans. Sometimes they are provided with a small amount of food and encouraged to move on. At other times they may be hit with sticks or scalded with boiling water as people try to turn them away from the village. Such encounters are becoming more, rather than less common, as oil palm expansion, habitat loss and conservation efforts drive orangutan population growth in the adjacent reserve area. At the same time the women have received support for small scale food and handicraft production to develop income streams that are not reliant on forest degradation, or more particularly forest carbon degradation. These encounters with orangutans are endured in pursuit of a community-based forest carbon project where social and biodiversity 'cobenefits' are positioned as unique selling points for the carbon credits generated through the project.

In the village of Bahanei, also in Central Kalimantan, efforts to govern forest carbon have resulted in some young people being trained in the use of Geographic Information Systems (GIS). They are mapping customary land, seeking to geographically determine village boundaries and land uses. The data they collect will be used by Aliansi Masyarakat Adat Nusantara (AMAN) - the leading Indigenous rights organization in Indonesia - to strengthen land claims and feed into the government's One Map Initiative. The Initiative is partly funded by forest carbon finance and is being developed by the Indonesian government to clarify land tenure and generate 'governable space' for carbon investment (Astuti and McGregor, 2017). Others are being trained in monitoring, reporting and verification technologies that enable forest carbon to be calculated and traded - forming new local institutions, opportunities and power relations linked to distant carbon markets.

These encounters, activities, livelihoods, maps, animals, plants, and forests are entangled with efforts to govern carbon through the Reducing Emissions from Deforestation and forest Degradation (REDD+) program. Broadly defined REDD+ is a multibillion dollar international initiative whose primary aim is to reduce emissions from deforestation and forest degradation and enhance carbon stocks in developing countries (Angelsen et al., 2012:381). REDD+ was originally designed to provide economic compensation to forest owners for protecting forests, by making them "more valuable standing than cut down" (Katerere, 2010:105). However, REDD+ continues to morph from its original conception, building on existing projects and relations to incorporate a much wider array of activities and meanings, transforming people and places in unexpected ways.

While biodiversity, community development and customary mapping projects have long histories in Indonesia, forest carbon finance is altering their focus and expanding their reach. If Indonesia abandons REDD+ and its attempts to govern forest carbon these lives, livelihoods and technologies become more precarious, depending on future forest governance priorities. Similarly, if orangutan populations decline, or cottage industries fail, or customary land claims are denied, or fire breaks out, carbon governance also becomes more precarious, and forest carbon projects are likely to fail. As such, carbon governance is about much more than carbon. It involves arranging humans and non-humans in ways that create verifiable forest carbon benefits. We use the term non-human to refer to the entities, ecologies, processes and phenomena that have the capacity to occur or continue independent of humans. This capacity ensures that carbon governance is a dynamic process where 
the relations and agency of human (e.g. foresters, investors, communities) and non-human actors (e.g. fire, orangutans, soils) continuously test and challenge those arrangements.

In this paper we draw on these and other pilot projects to unsettle the human-nature dualism that underlies REDD+ and many other programs of global environmental governance (Howell, 2013). We propose a new conceptual model - which we call the sociocarbon cycle - as an alternative way of understanding and pursuing carbon governance. The model takes inspiration from, and builds upon, Linton and Budds' (2014) conceptualization of the hydrosocial cycle, with which we see strong parallels. We approach carbon as a socionatural achievement, held together through a set of embedded cyclical relations, rather than an isolatable entity existing independent of context. In developing a sociocarbon approach we seek to make such relations, and the issues to which they give rise, more visible for researchers and practitioners. This allows technical projects of global environmental governance to be considered in much more integrated ways that go beyond well-trodden debates between critical anti-REDD+ researchers and pro-REDD+ practitioners (McGregor et al., 2015). Our approach emphasizes that attempts to manage and control carbon are simultaneously efforts to manage and control society.

In what follows we briefly review some key insights from the socionatures literature that contest human-nature dualisms. We cannot do justice to the breadth and depth of this rapidly unfolding field but draw some general insights to highlight problems within dominant approaches to forest carbon. We then explore how a socionatures approach may provide additional insights for forest carbon governance and develop the concept of a sociocarbon cycle. The subsequent section places the research in Indonesia, where we apply the concept of the sociocarbon cycle to better understand how REDD+ is transforming carbon governance in the country. We focus on relations that have formed between institutions, technologies, and $\mathrm{C}$ atoms to constitute sociocarbon cycles and forest carbon in Indonesia, and their influence on existing geometries of power. The paper concludes with some reflections on the advantages of this approach in an era of climate change and global environmental governance.

\section{Socionatures}

The tenacious human-nature dualism that pervades so much modern thought and practice has come under sustained criticism over the past few decades (Bennett, 2010, Haraway, 2008, Latour, 1993, Whatmore, 2002). Critics have challenged the idea that there is a knowable nature 'out there' that is distinct from and separate to human society, and that human activity and society can be abstracted or removed from the broader contexts in which they are embedded. It is argued instead that humans and non-humans are inseparably entangled in diverse relations that evolve, or become, together. Narratives of human exceptionalism are critiqued and attention is instead being directed to broader more-than-human assemblages through which the world becomes. Traditional academic divisions of labour that enabled the 'natural' sciences to focus on the bio-physical dimensions of nature, and the social sciences upon the workings of society and culture, are collapsed as the relations between material and discursive worlds become more apparent (Latour, 1993).

There is now an extensive literature experimenting with these ways of knowing the world. Some Indigenous researchers, for example, have described the complex entanglements involving humans and non-humans and the non-human agencies that compose worlds in difference ways (see Watson and Huntington, 2008). In parallel, but often with limited engagement with existing Indigenous literature (Todd, 2016), novel terms like hybridity, assemblage, co-production, more-than-human, 
post-human, socio-material, global ecology and socionatures have emerged as conceptual tools to explore such relations. Related, but distinct concepts, such as Coupled Human and Natural Systems (CHANS) (Liu et al., 2007) and socioecological systems (Folke et al., 2005), that seek (with varying degrees of success) to bridge the human nature divide, are finding their way into policy contexts. In this paper, we use the term socionatures to refer to this broad body of work focused on the hybrid more-than-human constitution of contemporary phenomena.

Perhaps the most important insights from these bodies of work relate to agency and materiality (Bakker and Bridge, 2006). Common conceptions of agency associate it with intentionality, and therefore predominantly (although not exclusively) with human actors who express agency through their decision-making, strategy and behaviour. Within socionatural work, agency is considered more in terms of the sets of relations that produce particular outcomes and is conceived more broadly through the ability to shape the world. As such agency extends beyond the human, as it no longer requires conscious decision-making (while recognizing that many non-human life forms possess consciousness). Instead agency derives from material relations between things - what Jane Bennett (2010) refers to as vital materialism. As a simple example rain has agency in that it enables plants to grow which then provides food for insects, animals and rural economies, or rain can work with soil and rivers to cause flooding or riverbank erosion - in both cases rain is actively producing and reworking the world. Rain events are also outcomes of different material agencies - such as climatic conditions and evaporative processes. The modernist view of the world as a set of deanimated objects upon which humans impose their will, is transformed into a much richer animated world of vibrant interacting agencies of which humans are a part (Latour, 2014). Humans, orangutans, birds, trees, winds, maps, vehicles and roads, all exhibit this more diffuse form of agency, continually negotiating and responding to the dynamism of one another.

Democratising agency in this way raises questions about how sets of relations come to be arranged in ways that enable particular outcomes. The concept of assemblage provides a conceptual framework for thinking through how sets of relations form and are sustained. Drawing on the work of Deleuze and Guattari, 1987, Müller, 2015 interprets assemblage as "a mode of ordering heterogeneous entities so that they work together for a certain time" towards particular ends. Their heterogeneity means "humans, animals, things and ideas" (Müller, 2015:29) co-constitute assemblages, and that no one component is necessarily in charge, instead they are co-evolving according to interactions among component parts. This leads to instability, with assemblages continually forming, reforming and disassembling, thereby inviting investigations into the "hard work required to draw heterogeneous elements together... and [how to] sustain these connections in the face of tension" (Li, 2007:264).

The agencies of forests in absorbing carbon dioxide or providing habitats are dependent on evolving assemblages (including laws, policies, politics, weather, climate, fire, photosynthesis, orangutans, customs and practices) that shape how the forest grows. The removal of or change in any part of that assemblage - such as a change of government, a new land title, a drought, an extinction, or a forest fire - affects the whole. Researchers have analysed how and why assemblages form and hold together (Li, 2007), processes of configuration (McGuirk et al., 2016), and the geometries of power that produce and are produced by them (Swyngedouw, 2005). By focusing on geometries of power, which we treat here as the spatialized sets of power relations that shape how and where assemblages form and the strategies they adopt, researchers can "push beyond merely recognizing and describing socioecological dynamics (in all their complexity) toward evaluating them" (Mansfield et al., 2015: 292). Following Massey (2009:19) power geometries provides a means "through which to analyse the world, in order perhaps, to highlight inequalities or deficiencies in democracy ... [or] be an instrument through which to imagine, and maybe to begin to build, more equal and democratic societies." In this 
way agency becomes politicized, with particular actors influencing the formation and direction of assemblages towards progressive or regressive ends, via uneven encounters with the agencies of actors within.

Concerns about global climate change have sparked critical interest in the materialities and assemblages involved in efforts to govern carbon. Bumpus (2011), for example, has explored the socionatural-technical complexes required to calculate and produce carbon offsets, where the materialities of carbon shape the type, complexity and costs of the assemblages required. Carbon trapped in refrigeration units as HCFCs is much more cooperative and calculable, from a governance or management perspective, than carbon found in forests, where human and non-human agencies shape processes of carbon sequestration and storage. Lansing (2012) outlines the intricate and fragile performativities required to fix, map and calculate forest carbon, and how these actions come to constitute carbon economies, subjectivities, cultures, and communities. From a socionatures perspective then, carbon governance involves sets of world-making practices that attempt to arrange unruly assemblages of diverse human and non-human actors in ways that enable carbon to materialize in particular biophysical states or forms.

\section{Sociocarbon}

One of the challenges for socionatures researchers is to translate the often-dense writing around this topic into more accessible forms that will be of interest and of use to policy makers and practitioners grappling with challenges of environmental change. In this paper we respond to this challenge by proposing the idea of a sociocarbon cycle as a heuristic device for thinking about the hybrid nature of carbon within carbon governance. We draw on the concept of a cycle for three reasons: it builds from a concept already familiar to many grappling with carbon governance - the biophysical carbon cycle; it draws upon conceptual work already conducted on the hydrosocial cycle, with which we see strong parallels; and it captures the ongoing feedback and adaptation mechanisms inherent in resource management - something less explicitly recognized in an assemblage-style approach.

The biophysical carbon cycle is a well-established concept within the earth sciences that tracks the journey of carbon atoms as they transition through different biophysical forms - water, atmosphere, biomass, and earth (Fig. 1). Based on a mechanistic view of nature it allows the movement of carbon to be predicted through increasingly sophisticated modelling. Much of the work by the Intergovernmental Panel on Climate Change (IPCC) focuses on understanding and calculating changes to the cycle and the consequences of accumulating carbon (and other greenhouse gases) in the atmosphere under a range of scenarios. Such work has highlighted human influences in contributing to and responding to changes in the carbon cycle, however the conceptual distinction between humans and nature is maintained - it is human impacts on the carbon cycle and its impact on humans that are of interest. The carbon cycle is depicted as an object or predictable process separate from, and ultimately controllable through, human ingenuity. 


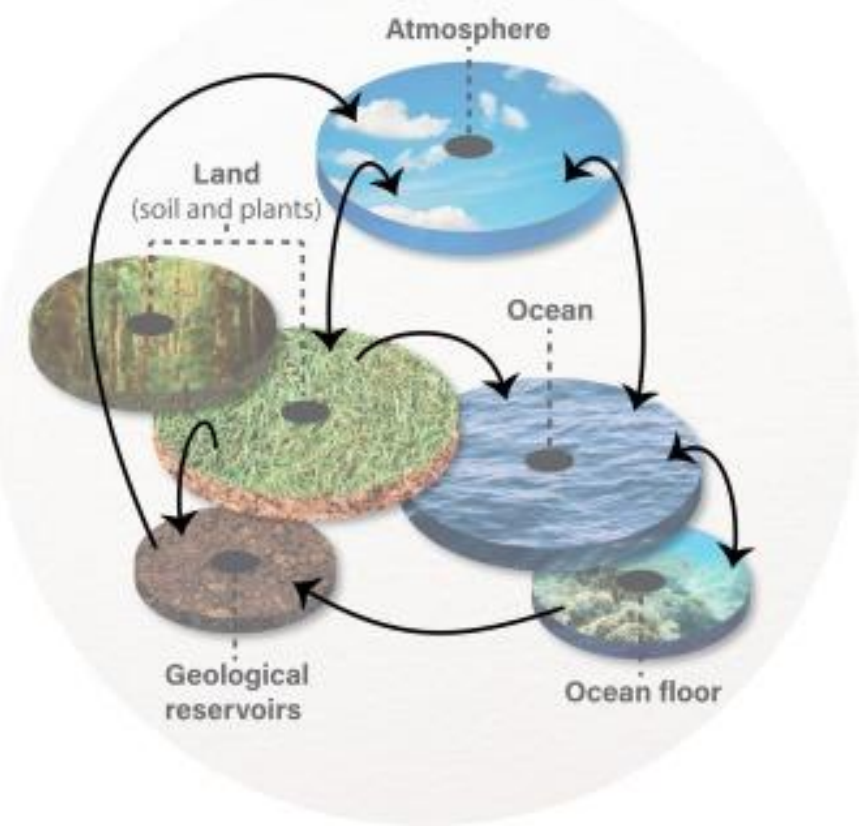

Fig. 1. The biophysical carbon cycle.

The pervasive and seemingly immutable challenges of climate change, however, encourage novel approaches that stress the interconnectedness of humans with the biophysical carbon cycle. Rather than being distinct from human societies, carbon is an essential element within them. Soil carbon influences plant growth, biodiversity and agricultural production; fossil and ocean floor carbon have powered industrial revolutions, colonialism, and wars (Mitchell, 2011); ocean carbon is essential for microalgae, fish, estuaries, and fisheries; and atmospheric carbon plays a major role in (de)stabilizing climates and is now the subject of a rapidly expanding carbon industry. Where and how carbon accumulates is internally tied to social organization and development. The biophysical focus of the carbon cycle subtly diverts attention away from these relationships, however it is now providing a useful way of linking seemingly unrelated activities. Whereas in the past humans burned fuels or cleared land with little thought about carbon per se, the global perspective of climate science connects these activities in attempts to govern atmospheric carbon. However, carbon retains a 'deanimated' status, as an object that can be governed and is separable from human subjects (Latour, 2014). Carbon governance has generally focused either on mitigating the flows of carbon into the atmosphere, or on minimizing impacts on human societies through adaptation. Market mechanisms to govern carbon further encourage the abstraction, calculation, standardization and trade of fungible carbon units, largely independent of the socionatural relationships in which they are embedded (Lohmann, 2011).

Our sociocarbon approach positions carbon quite differently - emphasizing its inseparability from the social and ecological processes that constitute it. We draw inspiration from Linton and Budds' (2014) conceptualization of the hydrosocial cycle where the geography, constitution and meanings of what we know as water are positioned as the outcomes of an ongoing cyclical process involving three different sets of agents. In the hydrosocial cycle, the first set of agents are the relevant social structures, institutions and associated power relations; the second focuses on the materiality and agency of technology and infrastructure; and the third focuses on the agency of $\mathrm{H} 2 \mathrm{O}$ molecules themselves. A change in one component of the hydrosocial cycle, such as a change in law, policy or ownership, or new hydropower or filtration technologies, or intense rain, flooding or drought, 
necessitates changes in all other elements in an ongoing cyclical process. Importantly, this work distinguishes between the $\mathrm{H} 2 \mathrm{O}$ molecules that are the molecular compounds within hydrological cycles, and the meanings, ideas and power relations associated with 'water' that are produced through, and reproduce, the hydrosocial cycle. In this conceptualization water and society are shown to be internally entwined, and continually co-evolving and remaking one another.

Similar cyclic relations can be seen in attempts to govern carbon. A diverse range of institutions, social structures, and associated power relations, have evolved alongside efforts to govern carbon - such as the IPCC, the United Nations Framework Convention on Climate Change (UNFCCC), national climate change agencies, carbon investors and carbon standards. They work with and respond to emerging carbon technologies and infrastructure, such as carbon markets, offset mechanisms, and evolving monitoring and measurement methodologies. These institutions and technologies reflect the agency of $\mathrm{C}$ atoms, which are taken here to include the many compounds that include $\mathrm{C}$ atoms, such as $\mathrm{CO} 2$ or $\mathrm{CH} 4$, as well as the material forms through which $\mathrm{C}$ atoms cycle, such as plants, human and nonhuman animals, socioecological systems, soils, atmospheres, and oceans. We distinguish $\mathrm{C}$ atoms referring to a chemical element - from carbon, which is the material-semiotic outcome produced through the assemblage of atoms, technologies, instruments, knowledges and institutions. While $C$ atoms pre-exist life on earth, carbon is a much more recent socionatural construction entangled with the ontologies and epistemologies of Western science.

As Fig. 2 shows, from a sociocarbon perspective, attempts to govern carbon mean engaging with cyclical interactions between carbon institutions and social structures, emerging carbon technologies and infrastructure, and the vibrancy of $\mathrm{C}$ atoms in different material forms. Changes in one part of the cycle, such as establishing an emissions target, necessitate changes in all other parts of the cycle. This may include establishing a new monitoring body and associated policies, particular measurement and verification technologies, skills and infrastructure, and the cooperation of $\mathrm{C}$ atoms to behave in predictable and measurable ways. Human and non-human life is inseparably entangled with $\mathrm{C}$ atoms, being partly constituted by $C$ atoms, and reliant on $C$ atoms within food, habitat, livelihoods and climatic conditions, and hence actively shaping and shaped by the social structures, institutions and technologies of carbon governance. Sociocarbon cycles reflect these lively agencies as well as broader pre-existing political ecologies arranged around particular agencies of $C$ atoms, such as those associated with fossil fuel, forestry or agricultural industries. As such, sociocarbon cycles do not emerge in a vacuum and nor are they uniform. Instead they vary across time and space, building from the relations that preceded them. 


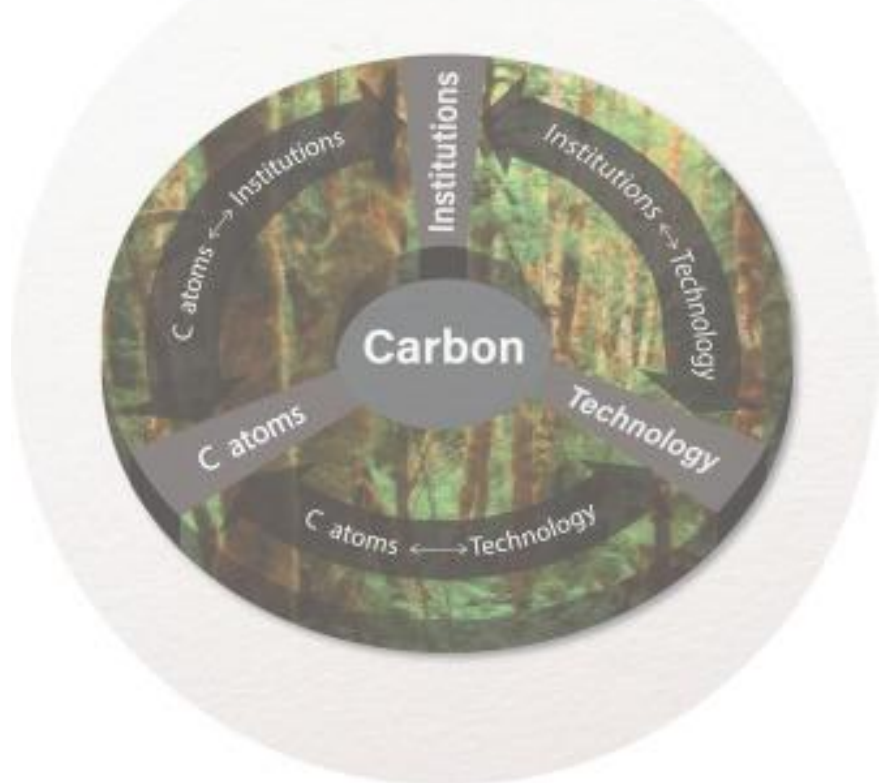

Fig. 2. The sociocarbon cycle.

Of course there are other broader assemblages at play - the weather for example can influence carbon sequestration, or electoral priorities may stall climate action. However, focusing in on three influential components at the centre of carbon governance assemblages, and emphasizing their interrelatedness, highlights the socionatural composition of what is normally considered a biophysical object. As such, the sociocarbon cycle opens up new ways of conceptualizing and approaching carbon. As carbon and society are constantly co-constituting one another, and here society is broadly conceived as a socionatural or multispecies achievement, any shift in the properties of carbon necessarily implies associated shifts in society. Governing carbon, in this sense, entails governing society and vice versa. It also implies a more subtle shift; rather than governing an isolated inanimate object, governance requires working with an animated integrated subject, one whose materiality and agency are actively reworking the world, just as humans seek to rework it.

The potential value of this conceptual maneuver is considerable. First, in emphasizing the sociality of carbon it heightens the importance of social research. Whereas the biophysical carbon cycle privileges scientific knowledge, the sociocarbon cycle suggests that such knowledge only tells part of the story. If the ocean is absorbing greater amounts of carbon, what are the social dimensions of this shift what types of sociocarbon relations are constituting and being constituted by ocean carbonization? Similarly, efforts to increase plant biomass or pursue carbon capture and storage, as a means of absorbing atmospheric carbon, are reliant upon the technologies and social structures that enable this to be done. A second, related benefit derives from the greater visibility justice issues are likely to receive through a sociocarbon lens. If carbon governance is remaking society, analysis can and should be directed to the socially progressive or regressive elements of that remaking - what new power geometries are being formed, who wins and who loses from carbon initiatives, and how can injustices be addressed? A third, more conceptual benefit is in understanding what carbon is and how it is made known. The vitality of $\mathrm{C}$ atoms and their many material forms requires expert knowledges, practices and technologies to define, locate and confirm carbon. For example, the marketization and commodification of carbon as a tradeable emissions reduction is dependent on a wide range of conventions, practices, rules, standards and institutions that render carbon knowable and verify and track its production and exchange. As such multiple sociocarbon cycles can coexist at any one time as 
different institutions and methodologies engage and interact with $C$ atoms in diverse ways, constituting competing carbon claims and knowledges.

The sociocarbon cycle focuses attention on these institutions, technologies and materialities that produce carbon as a calculable object. This allows the biophysical carbon cycle to be re-conceptualized as embedded with sociocarbon cycles (Fig. 3), highlighting the interplay and interdependence between human activity and the movement of carbon through society. It is with this framework in mind that we draw on the unfolding REDD+ program in Indonesia to explore the usefulness a sociocarbon approach.

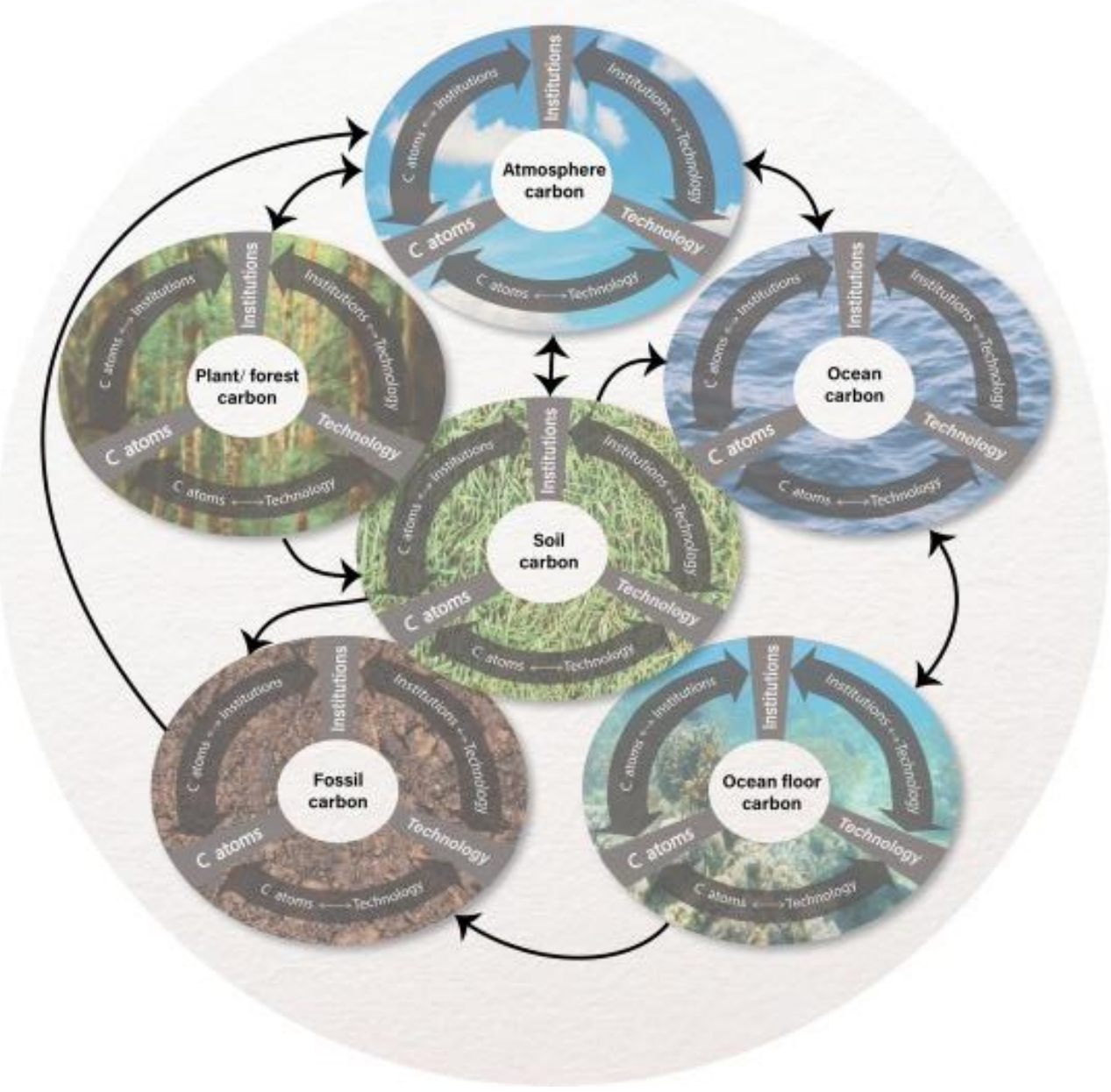

Fig. 3. Sociocarbon cycles within the biophysical carbon cycle.

\section{Exploring REDD+ in Indonesia}

In what follows we explore how a sociocarbon approach provides new ways of interpreting and practicing REDD+ in Indonesia by focusing on the relations constituting the program. Our discussion is based on a Marsden funded research project that ran from 2012 to 2016, examining the political ecology of REDD+ in Indonesia. The project involved researchers from Aotearoa / New Zealand, Indonesia, Australia, Germany and the United States and sought to understand how REDD+ was transforming forest governance at three institutional scales - international, national and local. Small teams formed to focus on each scale of governance, with three $\mathrm{PhD}$ researchers driving the empirical research program. Two Central Kalimantan case study areas - Sungai Lamandau and Bahanei - were 
the main, but not only, focal points for the local scale research. Close to 400 semi-structured interviews were conducted across five years involving government, civil society, private, multilateral, donor, and community stakeholders. These activities were accompanied by participant observation and long periods of ethnographic work based in Indonesia. The project was influenced by debates in political ecology and primarily focused on neoliberal, governmental and environmental justice elements of REDD+. The advantage of the multiscalar analysis has been to make the connections between corporate boardrooms, government policies, and human and non-human lives and livelihoods less opaque. It is these linkages that inspired the conceptual framing of this paper.

The project focused on Indonesia as it has one of the world's highest rates of deforestation and has consequently attracted a high level of REDD+ investment. The REDD+ program is the latest in a long series of attempts to reform the governance of Indonesia's forests. The foundations of forest governance issues in the post-colonial period derive from the Basic Forestry Law, introduced in 1967 during the Suharto era, in which the state laid claim to over $70 \%$ of the country officially designated as forested (Kuwasan Hutan). Supporters of the Suharto regime were favoured in the allocation of forest concessions for extractive enterprises, contributing to high rates of deforestation as well as the repression of millions of people who lived in and relied on forest spaces for their livelihoods (Peluso, 2007). In the post-Suharto Reformasi era many natural resource management responsibilities were devolved to district and provincial governments in line with a neo-liberal structural adjustment agenda, leading to an unexpected spike in deforestation as local actors sought to profit from the new arrangement both financially and politically. A subsequent revision of the Basic Forestry Law in 1999 reined in local governments by recentralizing some forest authority, while also retaining some local scale autonomy

These shifts in forest governance have taken place amidst a rapid expansion of plantation economies (most notably oil palm), rampant legal and illegal logging and mining, agricultural expansion at forest margins, and devastating forest fires (Abood et al., 2015). As a consequence, Indonesia has become the largest contributor of greenhouse gases from primary forest loss in the world, removing 840,000 ha of primary forest each year (Margono et al., 2014). REDD+ promises a means to address some of these issues, creating financial rewards for reductions in deforestation and forest degradation as well as for improved forest governance. Indonesia was a vocal supporter of the fledgling REDD+ program at the 2007 COP13 in Bali and in 2009 pledged to reduce emissions by 26\%, or $41 \%$ with international support, by 2020 (Luttrell et al., 2014). This declaration, and the socioecological context of forest governance in Indonesia has proved attractive to REDD+ proponents, with Norway pledging US\$1 billion for REDD+ development in country (Luttrell et al., 2014).

As the primary mechanism of the UNFCCC to address forest emissions, REDD+ has attracted a huge amount of research, far too much to be covered in any detail here (for a review see den Besten et al., 2014). Research has tended to be split between those working on the technical challenges of REDD+ implementation (including project design, governance systems, institutional architecture, carbon accounting integrity, payment systems, monitoring and emissions measurement technologies, safeguards, and policy) (see Sills et al., 2014) and more critical work investigating REDD+ with concerns for environmental justice, eco-governmentality, neo-liberalisation of nature, and conservation and development outcomes (see McGregor et al., 2014). Despite their different approaches both research trajectories emphasise that REDD+ is not currently working in Indonesia, with only a fraction of Norway's original \$1 billion result-based payment pledge finding its way into the country (Redford et al., 2013, Fletcher et al., 2016). Problematic issues include uncertainties in governance responsibilities; knowledge transfer and understanding; land tenure; law enforcement, corruption, institutional and local opposition; competing land uses and livelihood impacts; benefit sharing; measuring, reporting 
and verifying (MRV); access and exclusions and uneven power relations (Lund et al., 2017). Research tends to be compartmentalised, focusing on one aspect of REDD+ implementation or opposition, with deanimated $\mathrm{C}$ atoms implicitly positioned as objects to be controlled, or as separate to and distinct from issues of social justice, power and politics. In what follows we resist this compartmentalisation by applying the sociocarbon cycle to develop novel insights about REDD+ in Indonesia.

\section{REDD+ sociocarbon cycles in Indonesia}

REDD+ is predicated on governing the flux of $\mathrm{C}$ atoms between forests and the atmosphere. Finance is generated when expected flows of $\mathrm{C}$ atoms from forests to the atmosphere are slowed through avoided deforestation or degradation, or when the rate at which forests extract or sequester $\mathrm{C}$ atoms from the atmosphere is improved through afforestation and improved forest management. At its core then, REDD+ seeks to intervene in the biophysical carbon cycle for forest carbon gains. Societies are clearly a part of this cycle, as it is human actions that are driving forest degradation and conservation. However they are normally positioned as separate to and distinct from the movement of $C$ atoms. For example, measuring, reporting and verifying (MRV) $C$ atoms is at the centre of REDD+ Readiness programs, while social considerations generally enter via provisions for co-benefits and safeguards i.e. measures that seek to mitigate negative impacts (safeguards) and secure positive outcomes (cobenefits) from the movement of $\mathrm{C}$ atoms. This distinction is maintained within program methodologies where MRV technologies that focus on $\mathrm{C}$ atom calculations are prioritized, while safeguards and co-benefits are generally addressed separately and secondarily. This nature-society dualism (Howell, 2013) underpins fears that forest communities will be given secondary consideration behind the technical performance of REDD+ projects (Brown et al., 2008).

We begin from the observation that the social structures, technology and $\mathrm{C}$ atoms that are being assembled through the 'hard work' of REDD+ proponents are socionatural achievements. They are evolving in relational ways with changes in one component necessitating changes throughout the whole. Hence rather than focus on the more visible points or 'substances' (Emirbayer, 1997) within sociocarbon cycles - such as institutions or technology - we focus on the shifting and unstable relations that bind them together. In what follows we approach the sociocarbon cycle through three sets of interlinked relations that constitute the whole - the relations between technology and $\mathrm{C}$ atoms; $\mathrm{C}$ atoms and social structures; and social structures with technology. We provide two examples from each relation that demonstrate the types of insights that arise from this form of analysis. In each case we attempt to focus on the agency of multiple human and non-human actors and the worlds and power geometries being co-produced. The aim is to highlight the dynamism of relations rather than the temporary substances that are produced through them and are so often the focus of research.

\subsection{Relations between $C$ atoms and technology}

In this section we focus on the relations that have formed between $\mathrm{C}$ atoms, technology and infrastructure. We approach $\mathrm{C}$ atoms not as deanimated measurable objects but as dynamic agentic subjects whose behaviour and geography is co-evolving with the technologies and social structures around them. Two types of relations are considered here: atomic-scale technologies that have evolved to track the exchange of $\mathrm{C}$ atoms between forests and atmosphere; and the social technologies aimed at governing how human populations interact with the $\mathrm{C}$ atoms stored in forests. 
Tracking the flux of $\mathrm{C}$ atoms between forests and the atmosphere, or estimating the amount of $\mathrm{C}$ atoms that have been retained in forests through avoided deforestation, is a difficult and technicallychallenging process (Henders and Ostwald, 2012). The agency of $C$ atoms have necessitated the development of a wide range of forest carbon modelling knowledges and technologies that include temporal deforestation baselines, remote sensing and processing technologies, geographic information systems, forest carbon inventories, and verified carbon accounting systems (e.g. Angelsen, 2009, Angelsen et al., 2012). Indonesia's increasingly automated National Carbon Accounting System, for example, attempts to calculate the flows of $C$ atoms between the country's forests and the atmosphere using satellite data (Roswintiarti et al., 2013). These technologies are being continually updated according to recognised international standards in an attempt to make the fluxes of $\mathrm{C}$ atoms more visible, calculable, fungible, governable and tradable. They are relational achievements reflecting both the material agencies of $C$ atoms, evolving scientific knowledge, and multi-scalar political economies influencing research and funding.

A diverse range of social technologies have also evolved, oriented at governing how people interact with forests, and consequently the flux of $\mathrm{C}$ atoms between forests and the atmosphere. Free Prior Informed Consent (FPIC), for example, involves fraught consultation processes and procedures oriented at improving knowledge about $\mathrm{C}$ atom fluxes and gaining community support for REDD+ programs (Howell, 2015). Participatory MRV produces carbon livelihoods by training and paying people in project areas to measure and calculate $C$ atom fluxes (Beaudoin et al., 2016). Carbon mapping delineates the geographic distributions of $C$ atoms, territorialising what sorts of behaviours are permissible where, and enforced through various disciplinary technologies such as forest (carbon) guards (Astuti and McGregor, 2017, Nel, 2017). A national knowledge base on safeguards has been developed to couple successful $C$ atom sequestration in forests with improvements in socioecological conditions (Jagger and Rana, 2017). For each technology best practice guidelines are evolving that seeks to normalise social behaviours in ways that are compliant with enhanced accumulation of $C$ atoms in forests.

Both sets of relations are reshaping the conditions where humans and non-humans negotiate lives and livelihoods. These conditions are inflected with multi-scalar power relationships, de/legitimizing different types of knowledge and ways of knowing. International scientific expertise and practices, for example, are likely (or perhaps, in terms of carbon market compliance, are required) to be favoured over more local technologies and uses (Bailey et al., 2011). The co-evolution of $C$ atoms with technologies are producing techno-scientific research industries; carbon economies; carbon laws, regulations and policies; new forms of policing and criminality; education, training, occupations and livelihoods; and particular geographies of $C$ atoms and the socioecologies they support. Focusing on the relations between $C$ atoms and technology, rather than on either in isolation, recognises they produce much more than abstracted carbon calculations, instead having wide ranging impacts across scale and space.

\subsection{Relations between $\mathrm{C}$ atoms and social structures}

The relations between $C$ atoms and technology do not exist in a vacuum but flow through the social structures and institutions evolving with forest carbon. A vast cross-scalar forest carbon community comprised of carbon standards, markets, traders, buyers, and marketers, as well as project developers, consultants, managers, implementers, and village committees, has evolved in Indonesia and elsewhere. The existence of each institution, and its longevity and success is tied to their combined ability to govern and profit from how $\mathrm{C}$ atoms behave. In what follows we briefly review two examples 
where the relations between $\mathrm{C}$ atoms and institutions are transforming forest governance in unexpected ways.

At a national scale, the first example comes from the reinvigoration of Indigenous land claims. Astuti and McGregor (2017) argue that a new political conjuncture has emerged in forest politics whereby the secure property rights sought by REDD+ proponents, a national land use mapping project known as One Map, along with a Constitutional Court decision, have provided the conditions for Indigenous land claims to be mobilized. The umbrella Indigenous representative organization AMAN has strategically engaged with C atoms to promote and politicize Indigenous land rights (Afiff, 2016). It has benefited from the realization that carbon markets require clarity of land tenure in order to invest in and profit from spatially-specific $\mathrm{C}$ atom fluxes, something that is not possible while Indigenous groups contest ownership of ancestral land (Agung et al., 2014). AMAN played an essential role in supporting the agreement between Norway and Indonesia and is working with REDD+ institutions and infrastructures to produce new socioecological relations and spaces where the production of forest carbon is coupled with the production of Indigenous land rights (Afiff, 2016). Even where local community groups do not identify as Indigenous, many are strategically engaging with $C$ atoms to pursue local interests that challenge existing power relations (Howson, 2017). While success has varied, and opposition continues (see Eilenberg, 2015, Lounela, 2015), the enhanced visibility of Indigenous politics within forest governance is an outcome of AMAN's novel sociocarbon politics, in which the relation it has formed with $\mathrm{C}$ atoms has become a vehicle to advance land rights claims.

A second example is evident at a more local scale where the ability of $C$ atoms to fix themselves in trees and convert into carbohydrates has sustained the development of diverse socionatures and multispecies communities (see McGregor and Thomas, 2017). Some socioecologies house particular non-humans, such as Sumatran tigers or orangutans, which attract environmental NGOs as well as private sector institutions who are increasingly pursuing REDD+ as a form of corporate social responsibility (Dixon and Challies, 2015). As such, how $C$ atoms circulate through socioecological systems, and what sorts of human and non-human relations are sustained by it, influences where and how REDD+ projects and institutions locate. One of the first, most high profile but ultimately failed REDD+ projects, for example, was focused on the rich biodiverse areas of Ulu Masen and Leuser Ecosystems in the province of Aceh (McGregor, 2010). In this case diverse actors such as Carbon Conservation, Merrill Lynch, and Flora and Fauna International aligned with recently formed institutions like Aceh Green and the Aceh REDD+ Taskforce in an effort to form profitable relations with $\mathrm{C}$ atoms in forests, Sumatran tigers, rhinos, and orangutans. It is also why, as alluded to in the introduction, the Pendulangan community is encouraged to put up with disruptive orangutans, who actively contribute to the Climate Community and Biodiversity Alliance (CCBA) 'gold standard' certification that incentivises the production and sale of forest carbon from the area. In each case institutions have attempted to form relations with $\mathrm{C}$ atoms that are coupled with the preservation of particular non-human populations.

In both examples, institutions do not somehow pre-exist $\mathrm{C}$ atoms, instead institutional composition and activities emerge through relations with $\mathrm{C}$ atoms. For new institutions like Carbon Conservation and the Aceh REDD+ Taskforce, their existence was predicated on forming predictable relations with $\mathrm{C}$ atoms in forests - a relation that proved too hard to govern in post-conflict, post-disaster Aceh resulting in the disappearance of those institutions (Swainson, 2016). In other cases where REDD+ projects are unfolding relations have been temporarily established between institutions and $C$ atoms (see Indriatmoko et al., 2014), however these are fragile and unstable, always at risk of uncooperative agencies, such as fire, disease, land clearance, resistance, or policy change (see for example Sills et al., 
2014). As the experience of AMAN suggests however, recognizing $C$ atoms as animated actors, rather than deanimated objects, can provide new ways of challenging existing geometries of power.

\subsection{Relations between social structures and technology}

Just as $\mathrm{C}$ atoms are entangled with shifting landscapes of carbon institutions and technology, so too are those institutions and technologies co-evolving in relational ways with important consequences for the human and non-human actors involved. As work in science and technology studies has convincingly shown, technologies are not inert tools of institutions, but instead actively co-constitute those institutions as well as the broader socioecological relations with which they are entwined (Latour, 2004). Here we emphasise this more active interpretation of technology by focusing on how relations between technologies and institutions are reshaping power relations and governance within the forest sector.

Our first example relates to the former Ministry of Forestry (MoF), which was widely perceived to be lacking the knowledge, capacity, and confidence of various stakeholders to set up the infrastructure and technologies required to effectively produce carbon credits. Instead a REDD+ Taskforce was set up outside MoF to report directly to the President, a requirement of the billion dollar Norwegian funding agreement. The REDD+ Taskforce developed social technologies to incorporate perspectives from a wide range of government, civil society and private sector organizations that were previously excluded from opaque MoF decision-making processes (Astuti and McGregor, 2015a). The atomic and social technologies required to calculate, monitor, verify and sell the movement of $\mathrm{C}$ atoms saw an influx of international capital flow through to the REDD+ Taskforce, and its short-lived successor - the REDD+ Agency. For several years this threatened the MoF's authority over forest resources and saw other actors, including government, university, private sector and civil society institutions developing the infrastructure and technology required for REDD+ (Astuti and McGregor, 2015a). While the MoF, reconstructed as the Ministry of Environment and Forestry, has since repositioned itself more centrally within REDD+ negotiations, the technical challenge of measuring the flux of $C$ atoms has resulted in institutional changes and shifts in the geometries of power governing Indonesia's forests.

A second example emerges out of the production of forest carbon maps. Maps play a key role in visualizing carbon, furthering carbon territorialization, vilifying encroachment and configuring support for project development ( $\mathrm{Nel}, 2017)$. The maps are produced through satellite or aerial remote sensing in combination with the ground truthing of data to delineate areas of high forest carbon content. While such maps may appear as simple apolitical reflections of (new) realities, their production has been associated with considerable change within social structures and institutions at multiple scales. For example, efforts to identify forest carbon have exposed differences in the maps used by different Ministries in even identifying where forests are (Astuti and McGregor, 2015b). Recognition of this saw REDD+ funding channeled into the One Map Initiative, which made use of the types of participatory mapping approaches favoured by donors (Mulyani and Jepson, 2017). This mapping process has weakened institutional political ecologies that thrived in the opacity created by overlapping and contradictory maps, while, as mentioned previously, creating openings and opportunities for others (e.g. for Indigenous and other groups to make land claims). Civil society has also used maps, particularly the government's controversial forest moratorium map, to contest private sector logging concessions, alert authorities to breaches, and pursue legal action against deforestation (Afiff, 2016). As such mapping technologies have elicited institutional changes within government and between government and civil society, with NGOs acting as watchdogs for the state, whilst also contesting the maps the state produces. 
In both examples new relations between technology and institutions are shaking up existing geometries of power. The impacts stretch from the diminished role of $\mathrm{MoF}$, and its eventual reforming into the Ministry of Environment and Forestry, through to the new community institutions, skills and tensions evolving in REDD+ areas. In Central Kalimantan, for example, GIS is being used to create a map of community territory, complete with zones for what sort of activities are permissible where. This is creating antagonisms among neighboring communities who have previously shared resources, and is also forming new power geometries between villages (Astuti and McGregor, 2017, Howson, 2017). The mapping process can also inflame ethnic tensions as project developers distinguish between Indigenous districts that are more likely to be idealized as independent, self-reliant and empowered, and transmigrant villages that are dismissed as less authentic or merely 'Javanese' (Howson, 2017, Howson and Kindon, 2015). This contributes to changes in community-land relations that can challenge or reinforce already existing social inequalities and institutions. Transmigrants, women and other marginalized groups, for example, have generally had less access to program benefits, being excluded from the male-dominated community institutions that negotiated new relations with REDD+ technologies (Howson, 2017, Howson and Kindon, 2015, Lohmann, 2011, Siscawati and Mahaningtas, 2012).

\section{Shifting geometries of power}

The sociocarbon lens we are proposing advances understanding of carbon governance in a variety of ways. Most significantly it diverts attention from existing carbon-centric narratives that assess the impacts and success of the program according to verified emissions reductions. If we took this approach we could say that, for the amount of money invested in Indonesia, it has been a failure. These kinds of carbon-centric narratives are aligned with broader depoliticising processes that approach environmental issues as technical and fixable in supposedly apolitical ways (Swyngedouw, 2013). Our analysis instead brings the broad range of socioecological and highly political changes taking place as a consequence of REDD+ into view. Transformations have occurred in the political landscape of forest governance where new relationships between institutions, technology and infrastructure and $\mathrm{C}$ atoms have emerged, changing how and where REDD+ projects are implemented, and resisted (see Eilenberg, 2015, Lounela, 2015). REDD+ is as much, or more, about this broader range of transformations, as it is about verified carbon emissions reductions.

Focusing on the multiple relations that constitute sociocarbon cycles implies assessment of carbon governance projects not only on their atomic-scale efficiencies but also in terms of how they are reshaping geometries of power and whether these are moving towards more just and equitable socioecological outcomes. Researchers can focus on how and why sociocarbon cycles evolve in the ways they have, and what impacts they are having. Within Indonesia the development of sociocarbon cycles and all the institutions, infrastructure and agencies that come with that, has unsettled existing political ecologies, such as the plantation and extractive industries driving forest degradation. The autonomy of relevant Ministries has been shrunk, the Ministry of Forestry has merged with the Ministry of Environment, the transparency of land use and land claims has improved, logging moratoriums have been established, and new forest carbon priorities have been institutionalized alongside older ones. At the same time, international carbon markets, traders and developers, alongside for-profit banks and businesses have become involved in the forest sector and new allegiances and divisions have appeared in civil society landscapes. This is not to say that carbon forestry has replaced previous political ecologies of forest use - it clearly has not. However, existing power geometries are being challenged, altered and recreated in interesting ways that are often omitted from REDD+ research. 
We have also shown how local actors attempt to co-opt carbon initiatives to pursue progressive socioecological spaces. As McGuirk et al. (2014:138) note, carbon governance can "sediment existing governing orderings and [...] contribute towards the formation of transformative governance possibilities that may be both entangled with and exceed neoliberal governance forms". In this case, the revitalization of Indigenous politics has benefited from the active engagement of Indigenous organizations with REDD+ sociocarbon cycles. Indigenous communities have engaged with REDD+ to pursue historic land struggles that challenge geometries of power inherited from the Suharto era. This has been accompanied by new, more intimate sets of inclusions and exclusions deriving from local articulations of Indigenous politics (Howell, 2015, Astuti and McGregor, 2017). As such the sociocarbon cycle provides ways of examining how institutions, technologies and $\mathrm{C}$ atoms co-produce particular socioecological outcomes, and how different actors seek to shape those outcomes at different scales.

The practical and policy implications of a sociocarbon cycles approach are potentially significant for REDD+ as a program, and for climate change mitigation and adaptation interventions generally. The approach makes explicit the multitude of relations that shape, and are shaped by, attempts to govern forest carbon (or to render forest carbon governable). In highlighting the sociality of carbon, and in positioning carbon as the product of cyclic relations among $\mathrm{C}$ atoms, institutions and technologies, $\mathrm{a}$ sociocarbon lens opens up multiple points of entry for research, policy and action. For example, policy makers can focus on the sorts of relations they want to establish through REDD+, based on what sorts of principles, and direct attention to monitoring such relations. Rather than just calculating forest carbon, research can assess the quality of the relations that enable forest carbon to be calculated. The focus shifts to the worlds that are co-created through the production of forest carbon, who or what is being affected by those relations across space, scale and through multi-species communities. Very practical questions can be asked about how changes to REDD+ technologies, institutions or $\mathrm{C}$ atoms are reshaping socionatures in ways that go beyond the normal limits of safeguards analysis. For activists, recognizing REDD+ as a political project enabled by agencies within sociocarbon cycles provides multiple avenues to alter or reject these cycles in pursuit of more just geometries of power (Massey, 2009). The focus moves from governing carbon to exploring the desirability of the worldmaking sociocarbon relations that emerge.

To trace such relations policy makers and researchers need to draw on a wider spectrum of research approaches and knowledges, and attend to a wider range of agents and relations, to anticipate the implications of interventions. Our research suggests a need to explore the role of stories, such as those that briefly opened this paper, in illuminating shifting relationships. Pallett and Chilvers (2015) focus on stories as a way of capturing processes, relationships and the diversity of ways that these might be experienced. Stories, they argue, can focus on "various practices, memories and materialities" (p. 158), and may provide one methodological approach to research that is attentive to marginal groups including non-humans (Dowling et al., 2017). REDD+ already relies on stories that link REDD+ credits back to particular projects and outcomes 'on the ground'. These stories - of orangutan conservation, forest protection or community development - serve to sell REDD+ to socially and environmentally responsible corporations (Dixon and Challies, 2015), but they are also inevitably partial accounts, determined by certain parameters that have been identified as measurable and marketable. In contrast stories should be recognised as "sites of contestation over the meaning of places, resources and land use" (Houston, 2013, p. 419) and can be used to explore issues from environmental injustice (Houston, 2013) to climate change (Veland et al., 2018). A sociocarbon perspective can highlight whose stories get told and gain prominence, and enable the telling of alternative or unexpected stories that are currently obscured. 
The added complexity that emerges through revealing the hybrid nature of carbon does not simplify the task of those seeking to govern carbon and climate change. However, in recognizing this hybridity, REDD+ policy and practice may be better placed to approach forest carbon in an integrated way, which sees social and technological dimensions not as peripheral or secondary to movements of $C$ atoms, but rather as mutually constitutive, of forest carbon and its governance. A relational approach to forest carbon governance can prioritise forming more just cyclical relations between $\mathrm{C}$ atoms, technology and institutions. Research can focus on the nature and impacts of sociocarbon relations to inform a sociocarbon politics directed at making such relations more equitable, inclusive and progressive. Such approaches challenge much current work on safeguards and co-benefits that often adopts an apolitical approach in seeking to secure social and environmental gains from carbon programs. A relational approach draws attention to a wide range of potential inclusions and exclusions, justices and injustices, and progressive or repressive power relations, that form and reform as $\mathrm{C}$ atoms, institutions and technologies revolve through sociocarbon cycles.

\section{Conclusion}

In this paper we have proposed a new way of engaging with forest carbon projects, and climate governance more generally, that draws on insights from the socionatures literature. We have emphasized the inter-relationships, as opposed to the distinctions, among phenomena often categorized, and analysed, through human-nature dualisms. It is our contention that there is no way of governing carbon that is not simultaneously an attempt to govern society. Carbon is so entrenched in the functioning of societies, not just in terms of dependence on fossil fuels but also in fundamentally underpinning land based production globally (Scharlemann et al., 2014), that social structures and technologies inevitably bear its imprint. As carbon circulates through the global biophysical carbon cycle, societies also change through their internal relationalities. This is not to say carbon determines the structure of society in an environmentally determinist way, but rather that it is an important agent that is internally related to how societies evolve. Reconceptualizing the traditional global biophysical carbon cycle as embedded within sociocarbon cycles (Fig. 3) emphasizes human contributions to the cycling of carbon through different forms, and the movement of carbon though society.

Any attempt to govern carbon is really an attempt to govern sociocarbon cycles. In the case of REDD+, a sociocarbon approach highlights the relations that are reconfigured when project proponents distribute seemingly innocuous GIS technologies or form new forest carbon committees and institutions. Such interventions can be seen as efforts to redesign a sociocarbon cycle, not just the flow of $\mathrm{C}$ atoms, in ways amenable to global climate goals, reconfiguring power geometries and creating new winners and losers. As such the sociocarbon cycle can bring issues of justice, power, nonhuman agency, and the socioecological constitution of carbon programs into focus. It also highlights the diverse efforts and resources needed to make REDD+ work in the sense of governing $C$ fluxes, and arranging societies and technologies in amenable ways.

Furthermore, a sociocarbon approach challenges dominant approaches to forest carbon that decontextualize it by positioning it as a calculable and governable entity that exists separate to humans. Instead we have sought to recentre carbon within complex socionatural contexts, where the agency of $\mathrm{C}$ atoms influences the relations in which they are embedded. This process also enables a focus on power geometries capable of highlighting injustices. Focusing on relations and the ways societies, technologies and $\mathrm{C}$ atoms shift and rearrange allows for more nuanced responses to unpredictable non-human agency. For example, research might focus on highlighting or verifying stories that entangle humans and orangutans on the edge of the Sungai Lamandau Wildlife Reserve 
with carbon fluxes and markets, seeking more just outcomes from seemingly disconnected processes. In drawing attention to the relationships that make up sociocarbon cycles, we also seek to disrupt a reliance on, and privileging of, Western scientific or 'expert' knowledge in the management of carbon through flows of $\mathrm{C}$ atoms. Such a disruption may provide opportunities for alternative voices and perspectives to be shared and heard.

Finally, a sociocarbon approach provides a richer and more complete picture of what actually constitutes forest carbon. It is a socionatural construction comprised of institutions, technology, and $C$ atoms. What is calculated and verified, bought and sold, as forest carbon is socially and materially produced through the interactions of those in the cycle. A sociocarbon lens makes visible the hard work required to create forest carbon and its diverse socioecological consequences. Forest carbon is less a measurable entity or thing and more a rationality and practice produced through socionatural relationships that favour particular sets of relations at the expense of others.

\section{Acknowledgements}

The authors would like to acknowledge research funding provided by the Royal Society of New Zealand's Marsden Fund. We also appreciate and acknowledge the rich inputs made by Luca Tacconi, Sean Weaver and Rowan Dixon to the broader project, and to Sean Dunne for his creative work on the images. 


\section{References}

Abood, S. A., Lee, J. S. H., Burivalova, Z., Garcia-Ulloa, J., \& Koh, L. P. (2015). Relative contributions of the logging, fiber, oil palm, and mining industries to forest loss in Indonesia. Conservation Letters, 8(1), 58-67. https://doi.org/10.1111/conl.12103

Angelsen, A., Brockhaus, M., Sunderlin W. \& Verchot, L. (Eds.) (2012), Analysing REDD+ challenges and choices. Bogor, Indonesia: CIFOR.

Astuti, R., \& McGregor, A. (2015a). Governing carbon, transforming forest politics: A case study of Indonesia's REDD+ Task Force. Asia Pacific Viewpoint, 56(1), 21-36.

Astuti, R., \& McGregor, A. (2015b). Responding to the green economy: how REDD+ and the One Map Initiative are transforming forest governance in Indonesia. Third World Quarterly, 36(12), 22732293. https://doi.org/10.1080/01436597.2015.1082422

Astuti, R., \& McGregor, A. (2017). Indigenous land claims or green grabs? Inclusions and exclusions within forest carbon politics in Indonesia. The Journal of Peasant Studies, 44(2), 445-466.

https://doi.org/10.1080/03066150.2016.1197908

Bailey, I., Gouldson, A., \& Newell, P. (2011). Ecological modernisation and the governance of carbon: A critical analysis. Antipode, 43(3), 682-703. https://doi.org/10.1111/j.1467-8330.2011.00880.x

Bakker, K., \& Bridge, G. (2006). Material worlds? Resource geographies and the 'matter of nature'. Progress in Human Geography, 30(1), 5-27. https://doi.org/10.1191/0309132506ph588oa

Bennett, J. (2010). Vibrant Matter: a Political Ecology of Things. Durham; London: Duke University Press.

Brown, D., Seymour, F., \& Peskett, L. (2008). How do we achieve REDD co-benefits and avoid doing harm? In A. Angelsen (Ed.), Moving Ahead with Redd: Issues, Options, and Implications (pp. 107118). Bogor: CIFOR.

Bumpus, A. G. (2011). The matter of carbon: Understanding the materiality of tCO2e in carbon offsets. Antipode, 43(3), 612-638. https://doi.org/10.1111/j.1467-8330.2011.00879.x

Dalsgaard, S. \& Pedersen, M. (2015) The portable sawmill and other challenges to REDD+ in Papua New Guinea. Asia Pacific Viewpoint 56(1) 128-139.

Deleuze, G., \& Guattari, F. (1987). A Thousand Plateaus: Capitalism and Schizophrenia. Minneapolis: University of Minnesota Press.

den Besten, J. W., Arts, B., \& Verkooijen, P. (2014). The evolution of REDD+: An analysis of discursiveinstitutional dynamics. Environmental Science \& Policy, 35(Supplement C), 40-48.

https://doi.org/10.1016/j.envsci.2013.03.009

Dixon, R., \& Challies, E. (2015). Making REDD+ pay: Shifting rationales and tactics of private finance and the governance of avoided deforestation in Indonesia. Asia Pacific Viewpoint, 56(1), 6-20. https://doi.org/10.1111/apv.12085

Eilenberg, M. (2015). Shades of green and REDD: Local and global contestations over the value of forest versus plantation development on the Indonesian forest frontier. Asia Pacific Viewpoint, 56(1), 48-61. https://doi.org/10.1111/apv.12084 
Folke, C., Hahn, T., Olsson, P., \& Norberg, J. (2005). Adaptive governance of social-ecological systems. Annual Review of Environment and Resources, 30(1), 441-473.

https://doi.org/10.1146/annurev.energy.30.050504.144511

Haraway, D. (2008). When Species Meet. Minneapolis; London: University of Minnesota Press.

Howell, S. (2013). Divide and Rule: Nature and Society in a Global Forest Programme, In Kirsten Hastrup (ed.). Anthropology and Nature. London: Routledge 147 - 166 ISBN 978-0-203-79536-1

Howell, S. (2015). Politics of appearances: Some reasons why the UN-REDD project in Central Sulawesi failed to unite the various stakeholders. Asia Pacific Viewpoint, 56(1), 37-47. https://doi.org/10.1111/apv.12081

Howson, P. (2017). Intimate exclusions from the REDD+ forests of Sungai Lamandau, Indonesia. Conservation and Society, 15(2), 125. https://doi.org/10.4103/0972-4923.204071

Howson, P., \& Kindon, S. (2015). Analysing access to the local REDD+ benefits of Sungai Lamandau, Central Kalimantan, Indonesia - Howson - 2015 - Asia Pacific Viewpoint - Wiley Online Library. Asia Pacific Viewpoint, 56(1), 96-110.

Katerere, Y. (2010) A climate change solution? World Finance, May-June, 104-106

Lansing, D. M. (2012). Performing carbon's materiality: The production of carbon offsets and the framing of exchange. Environment and Planning A, 44(1), 204-220. https://doi.org/10.1068/a44112

Latour, B. (1993). We Have Never Been Modern. Cambridge, MA: Harvard University Press.

Latour, B. (2014). Agency at the time of the Anthropocene. New Literary History, 45(1), 1-18. https://doi.org/10.1353/nlh.2014.0003

Li, T. M. (2007). Practices of assemblage and community forest management. Economy and Society, 36(2), 263-293. https://doi.org/10.1080/03085140701254308

Linton, J., \& Budds, J. (2014). The hydrosocial cycle: Defining and mobilizing a relational-dialectical approach to water. Geoforum, 57(Supplement C), 170-180.

https://doi.org/10.1016/j.geoforum.2013.10.008

Liu, J., Dietz, T., Carpenter, S. R., Folke, C., Alberti, M., Redman, C. L., ... Provencher, W. (2007). Coupled human and natural systems. AMBIO: A Journal of the Human Environment, 36(8), 639-649. https://doi.org/10.1579/0044-7447(2007)36[639:CHANS]2.0.CO;2

Lohmann, L. (2011). The endless algebra of climate markets. Capitalism Nature Socialism 22, 4, 93 116.

Lounela, A. (2015). Climate change disputes and justice in Central Kalimantan, Indonesia. Asia Pacific Viewpoint, 56(1), 62-78. https://doi.org/10.1111/apv.12088

Mansfield, B., Biermann, C., McSweeney, K., Law, J., Gallemore, C., Horner, L., \& Munroe, D. K. (2015). Environmental politics after nature: conflicting socioecological futures. Annals of the Association of American Geographers, 105(2), 284-293

Margono, B. A., Potapov, P. V., Turubanova, S., Stolle, F., \& Hansen, M. C. (2014). Primary forest cover loss in Indonesia over 2000-2012. Nature Climate Change, 4(8), 730-735. 
Massey, D. (2009). Concepts of space and power in theory and in political practice. Documents D'Anàlisi Geogràfica 55, 15-26.

McGregor, A. (2010). Green and REDD? Towards a political ecology of deforestation in Aceh, Indonesia. Human Geography, 3(2), 21-34.

McGregor, A., Challies, E., Howson, P., Astuti, R., Dixon, R., Haalboom, B., ... Afiff, S. (2015). Beyond carbon, more than forest? REDD+ governmentality in Indonesia. Environment and Planning $A, 47(1)$, 138-155. https://doi.org/10.1068/a140054p

McGregor, A., \& Thomas, A. (2017). Forest-led development? A more-than-human approach to forests in Southeast Asia. In A. McGregor, F. Miller, \& L. Law (Eds.), Routledge Handbook of Southeast Asian Development. Routledge: London.

McGuirk, P. M., Bulkeley, H., \& Dowling, R. (2014). Practices, programs and projects of urban carbon governance: Perspectives from the Australian city. Geoforum, 52(Supplement C), 137-147. https://doi.org/10.1016/j.geoforum.2014.01.007

McGuirk, P. M., Bulkeley, H., \& Dowling, R. (2016). Configuring urban carbon governance: Insights from Sydney, Australia. Annals of the American Association of Geographers, 106(1), 145-166.

Mitchell, T. (2011). Carbon democracy: political power in the age of oil. Verso: London.

Müller, M. (2015). Assemblages and actor-networks: Rethinking socio-material power, politics and space. Geography Compass, 9(1), 27-41. https://doi.org/10.1111/gec3.12192

Nel, A. (2017). Contested carbon: Carbon forestry as a speculatively virtual, falteringly material and disputed territorial assemblage. Geoforum, 81(Supplement C), 144-152.

https://doi.org/10.1016/j.geoforum.2017.03.007

Paoli, G., Wells, P., Meijaard, E., Struebig, M., Marshall, A., Obidzinski, K., Tan, A., Rafiastanto, A., Yaap, B., Slik, J., Morel, A., Perumal, B., Wielaard, N., Husson, S., D'Arcy, L. (2010). Biodiversity conservation in the REDD. Carbon Balance and Management 5(7), 1-9 doi:10.1186/1750-0680-5-7

Peluso, N. L. (2007). Violence, decentralization, and resource access in Indonesia. Peace Review: A Journal of Social Justice, 19(1), 23-32.

Scharlemann, J. P. W., Tanner, E. V. J., Hiederer, R., \& Kapos, V. (2014). Global soil carbon: Understanding and managing the largest terrestrial carbon pool. Carbon Management, 5(1), 81-91. doi: $10.4155 / \mathrm{cmt} .13 .7$

Siscawati, M. and Mahaningtas, A. (2012) Gender justice: forest tenure and forest governance in Indonesia. Rights and Resources Initiative Brief 3, pp 1-18.

Swyngedouw, E. (2005). Governance innovation and the citizen: The Janus face of governancebeyond-the-state. Urban Studies, 42(11), 1991-2006. https://doi.org/10.1080/00420980500279869

Swyngedouw, E. (2013). The non - political politics of climate change. ACME, 12(1), 1 - 8.

Tacconi, L., Jotzo, F., \& Grafton, R. Q. (2008). Local causes, regional co-operation and global financing for environmental problems: the case of Southeast Asian Haze pollution. International Environmental Agreements: Politics, Law and Economics, 8(1), 1-16.

https://doi.org/10.1007/s10784-007-9057-z 
Tacconi, L., Moore, P. F., \& Kaimowitz, D. (2007). Fires in tropical forests - what is really the problem? Lessons from Indonesia. Mitigation and Adaptation Strategies for Global Change, 12(1), 55-66. https://doi.org/10.1007/s11027-006-9040-y

To, P., Dressler, W., \& Mahanty, S. (2017). REDD+ for Red Books? Negotiating rights to land and livelihoods through carbon governance in the Central Highlands of Vietnam. Geoforum, 81(Supplement C), 163-173. https://doi.org/10.1016/j.geoforum.2017.03.009

Todd, Z. (2016). An Indigenous feminist's take on the ontological turn: "Ontology" is just another word for colonialism. Journal of Historical Sociology, 29(1), 4-22.

Watson, A., \& Huntington, O. H. (2008). They're here-I can feel them: the epistemic spaces of Indigenous and Western Knowledges. Social \& Cultural Geography, 9(3), 257-281.

https://doi.org/10.1080/14649360801990488

Weis, T. (2013). The Ecological Hoofprint: The Global Burden of Industrial Livestock. London; New York: Zed Books.

Whatmore, S. (2002). Hybrid Geographies: Natures Culture Spaces. London: Sage. 